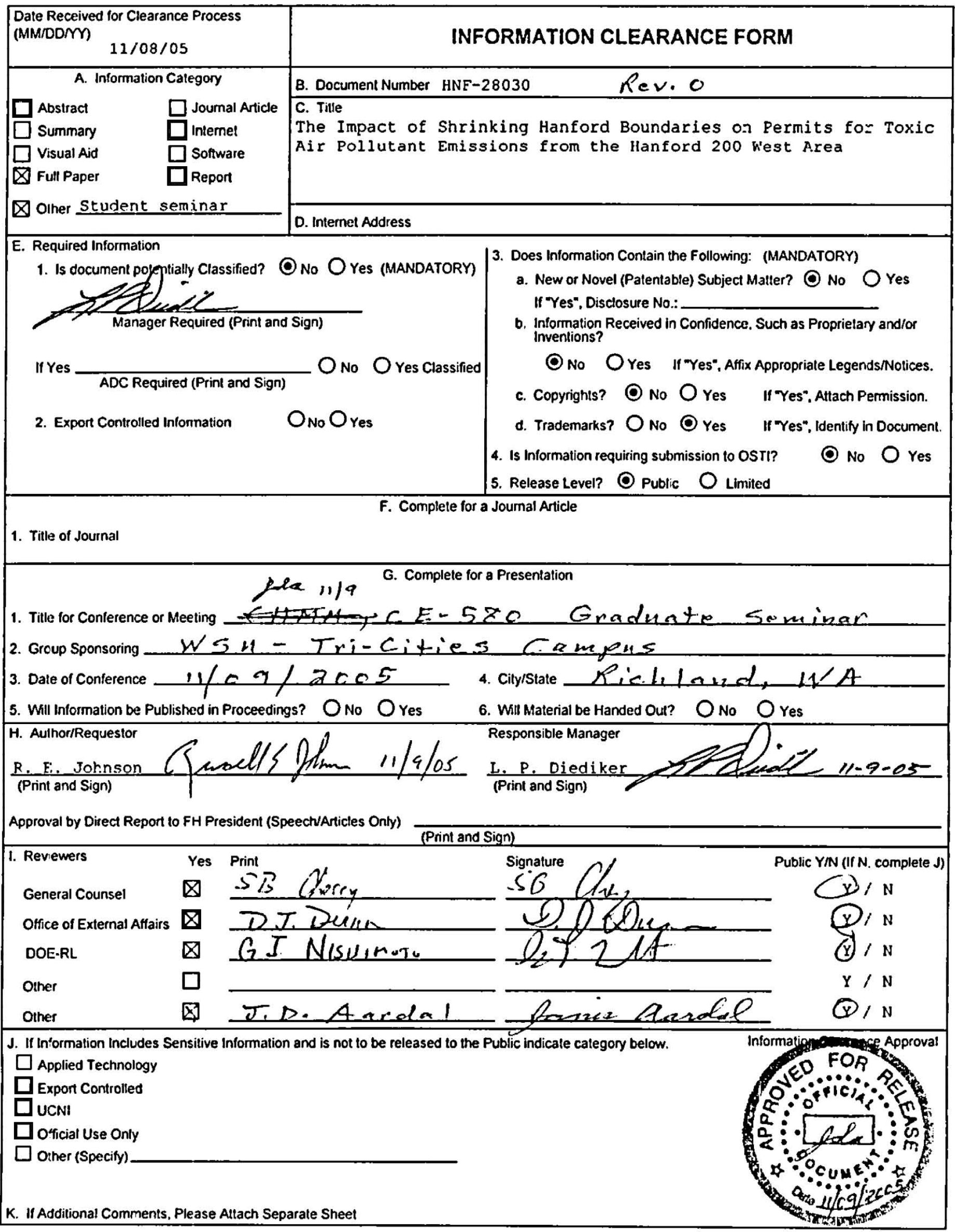


HNF-28030

Revision 0

\section{The Impact of Shrinking Hanford Boundaries on Permits for Toxic Air Pollutant Emissions from the Hanford 200 West Area}

Prepared for the U.S. Department of Energy

Assistant Secretary for Environmental Management

Project Hanford Management Contractor for the

U.S. Department of Energy under Contract DE-AC06-96RL13200

\section{Fluor Hanford}

P.O. Box 1000

Richland, Washington

Approved for Public Release;

Further Dissemination Unlimited 
HNF-28030

Revision 0

\section{The Impact of Shrinking Hanford Boundaries on Permits for Toxic Air Pollutant Emissions from the Hanford 200 West Area}

R. E. Johnson

Fluor Hanford

Date Published

November 2005

To Be Presented at

Graduate Seminar - CE-580

Washington State University (WSU) Tri-Cities Campus

Richland, WA

November 9, 2005

Prepared for the U.S. Department of Energy

Assistant Secretary for Environmental Management

Project Hanford Management Contractor for the

U.S. Department of Energy under Contract DE-AC06-96RL13200

\section{Fluor Hanford}

P.O. Box 1000

Richland, Washington

Copyright License

By acceptance of this article, the publisher and/or recipient acknowledges the U.S. Government's right to retain a nonexclusive, royalty-free license in and to any copyright covering this paper.
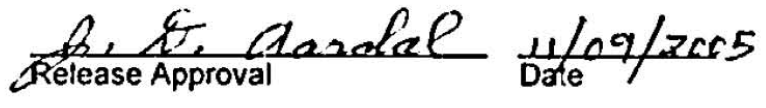

Approved for Public Release; Further Dissemination Unlimited 
HNF-28030

Revision 0

LEGAL DISCLAIMER

This report was prepared as an account of work sponsored by an agency of the United States Government. Neither the United States Government nor any agency thereof, nor any of their employees, nor any of their contractors, subcontractors or their employees, makes any warranty. express or implied, or assumes any legal liability or responsibility for the accuracy. completeness, or any third party's use or the results of such use of any information, apparatus, product, or process disclosed, or represents that its use would not infringe privately owned rights. Reference herein to any specific commercial product, process.

or service by trade name, trademark, manufacturer, or otherwise, does not necessarily constitute or imply its endorsement, recommendation, or favoring by the Uniled States Government or any agency thereof or its contractors or subcontractors. The views and opinions of authors expressed herein do not necessarily state or reflect those of the United States Government or any agency thereof.

This report has been reproduced from the best available copy. Available in paper copy. 


\title{
The Impact of Shrinking Hanford Boundaries on
Permits for Toxic Air Pollutant Emissions from the \\ The Impact of Shrinking Hanford Boundaries on
Permits for Toxic Air Pollutant Emissions from the Hanford 200 West Area
}

\author{
Russell E. Johnson. CHIMM \\ CE-580, WSU-Tri-citics \\ Fall Semester, 2005
}


HNF-28030, Revision 0

November 2005

\title{
The Impact of Shrinking Hanford Boundaries on Permits for Toxic Air Pollutant Emissions from the Hanford 200 West Area
}

\begin{abstract}
$\underline{\text { Abstract }}$
Russelt E. Johnson

This presentation (CE-580, Graduate Seminar) presents a brief description of an approach to use a simpler dispersion modeling method (SCREEN3) in conjunction with joint frequency tables for Hanford wind conditions to evaluate the impacts of shrinking the Hanford boundaries on the current permits for facilities in the 200 West Area. To fulfill requirements for the graduate student project (CE-702, Master's Special Problems), this evaluation will be completed and published over the next two years.
\end{abstract}

Air toxic emissions play an important role in environmental quality and require a state approved permit. One example relates to containers of waste that are designated as Transuranic Waste (TRU), which are required to have venting devices due to hydrogen generation. The Washington State Department of Ecology (Ecology) determined that the filters used did not meet the definition of a "pressure relief device" and that a permit application would have to be submitted by the Central Waste Complex (CWC) for criteria pollutant and toxic air pollutant (TAP) emissions in accordance with Washington Administrative Code (WAC) $173-400$ and $173-460$.

The permit application submitted in $\mathbf{2 0 0 0}$ to Ecology used Industrial Source Code III (ISCIII) dispersion modeling to demonstrate that it was not possible for $\mathrm{CWC}$ to release a sufficient quantity of fugitive Toxic Air Pollutant emissions that could exceed the Acceptable Source Impact Levels (ASILs) at the Hanford Site Boundary.

The modeled emission rates were based on the diurnal breathing in and out through the vented drums (approximately $20 \%$ of the drums), using published vapor pressure, molecular weight, and specific gravity data for all $600+$ compounds, with a conservative estimate of one exchange volume per day (208 liters per drum). 
Two permit applications were submitted also to Ecology for the Waste Receiving and Processing Facility and the T Plant Complex. Both permit applications were based on the Central Waste Complex approach, and relied on similar tracking requirements as at CWC. All three applications used ISCIII modeling, where unit release factors ( $\mathrm{lb} / \mathrm{yr}$ converted to $\mathrm{g} / \mathrm{s}$ ) were determined for estimating the highest 24 -hr or annual average concentrations (in $\mu \mathrm{g} / \mathrm{m}^{3}$ ), where the nearest public receptor was roughly 20 miles away.

Plans to clean up and release portions of the Hanford Site over the next several decades would allow public access closer to these facilities in the $\mathbf{2 0 0}$ West Area. Before release of these areas, effectively shrinking the boundaries, the three permits would have to be re-evaluated to determine if toxic air pollutant emissions would remain below the ASILs if the restricted boundaries are moved closer than the current locations.

\section{BACKGROUND}

The Central Waste Complex (CWC), a facility in the 200 West Area of the Hlanford Site, is a series of sturage buildings for waste containers with a total capacity of 88,500 drum equivalents. Containers of waste that are designated as transuranic (TRU) waste are required to have venting devices due to hydrogen generation. Ecology determined that the NucfFilim filters in use did not meet the definition of a" pressure relief device" and that a permit application would have to be submitted for CWC for critcria pollutant and toxic air pollutant (TAP) emissions in accordance with Washington Administrative Code (WAC) 173-400 and 173-460.

The permit application for CWC was prepared and submitted to Ecology in the spring of 2000. The modeled fugitive emissions of all 600+ TAP compounds were shown to be less than the acceptable source impact levels (ASILs) as defined in WAC-173-460. An ASIL is the risk based ambient concentration (annual ug/ $\mathrm{m}^{3}$ ) that would produce a cancer risk of one in one million for Class A compounds. The ASILs for Class B compounds are threshold based values derived from threshold limit values - time-weighted averages (TLVs-TWAs). The permit application (DOE-RL-200-21) used Industrial Source Code III dispersion modeling to demonstrate that it was not possible for CWC to release a sufficient quantity of fugitive TAP emissions that could exceed the ASILs at the Hanford Site boundary. The modeled emission rates were based on the diurnal breathing in and out through the 
NucFil ${ }^{(1)}$ filters on approximately $20 \%$ of the drums, using published vapor pressure, molecular weight, and specific gravity data for all 600+ compounds, with a conservative estimate of one exchange volume per day (208-L drum). CWC has no temperature or ventilation controls. According to staff the Hanford Meteorological Station, ambient day-time/night-time temperature deltas at the Ilanford Site for the past 30 years has been approximately $30^{\circ} \mathrm{F}$ throughout the year.

The strategy for the CWC permit application was successfully negotiated with Ecology, and the resultant approval order did not have any monitoring or control equipment requirements for CWC. but merely a graded approach for inventory tracking based on the number of vented containers received by CWC on an annual basis.

Two permit applications were submitted also to Ecology for the Waste Receiving and Processing Facility and the T Plant Complex. Both permit applications were based on the Central Waste Complex approach. and relied on similar tracking requirements as at CWC. All three applications used ISCIII modeling, where unit release factors ( $\mathrm{lb} / \mathrm{yr}$ converted to $\mathrm{g} / \mathrm{s}$ ) were determined for estimating the highest 24 -hr or annual average concentrations (in $\mu \mathrm{g} / \mathrm{m}^{3}$ ), where the nearest public receptor was roughly 20 miles away.

\section{AIR DISPERSION MIODELING}

Recommended air modeling techniques applied to New Source Review (NSR) and Prevention of Significant Deterioration (PSD) are found in 40 Code of Federal Regulations 51. Appendix W. Free downloads of certain dispersion models are available from EPA's Support Center for Regulatory Air Modeling (hun://www/epalgov/seram(01), while others are available from commercial suppliers. No single model is capable of addressing all conceivable situations.

The model required for PSD applications is CALPUF, which is a Lagrangian Dispersian model with multiple sources, multiple species, USGS coordinates and elevations, very detailed meteorological data, and huge computer resource requirements, often involving over 100 gigabytes of processed data and days to weeks of computer run

\footnotetext{
' NucFil ${ }^{\Phi}$ is a registered trademark of Nuclear Filter Technology, Inc.
} 
time. CALPUFF is mainly concerned with long range transport, and is generally much more complex than required for applications other than PSD permit applications.

Industrial Source Complex Model 3 is an intermediate air dispersion model that has been used at the Hanford Site for several applications, including the three referenced permits. It uses Gaussian dispersion for a nonreactive, continuous release, with hourly meteorological data (wind speed, direction, and stability class), and a choice of I-hr, 3-hr, 8-hr, 24-hr. or annual averaging times. Although ISC3 was used on the three referenced permit applications, comparisons to today's version are difficult, because of Windows $\mathrm{XP}^{\infty 2}$ compatibility issues and the difference in meteorological data treatment ( 36 sectors for short term ISCST3 and 16 sectors for long term ISCLT3).

SCREEN3 is a 2-dimensional Gaussian air dispersion model, for a continuous release, with 1-hr averaging times. The purpose of a screening modeling technique is to eliminate the need of more detailed modeling for those sources that clearly will not cause or contribute to ambient concentrations in excess of standards. SCREEN3 is very similar to ISC3, using the same dispersion equations, but is inherently conservative and much simpler and faster, due to elimination of the direction aspect.

Input parameters for SCREEN3 include: release rate (g/s); stack height; stack diameter; stack temperature; stack exit velocity; and stability class.

The following graphs indicate comparisons of a constant release rate with distance while varying the other five input parameters. Note that for distances of 10 to $30 \mathrm{~km}$, there is little variation, whereas there is a significant impact on ambient concentrations at distances between $100 \mathrm{~m}$ and $1 \mathrm{~km}$.

\footnotetext{
${ }^{2}$ Windows $\mathrm{XP} \mathrm{P}^{\oplus}$ is a registered trademark of Microsoft Corporation
} 
HNF-28030, Revision 0

November 2005

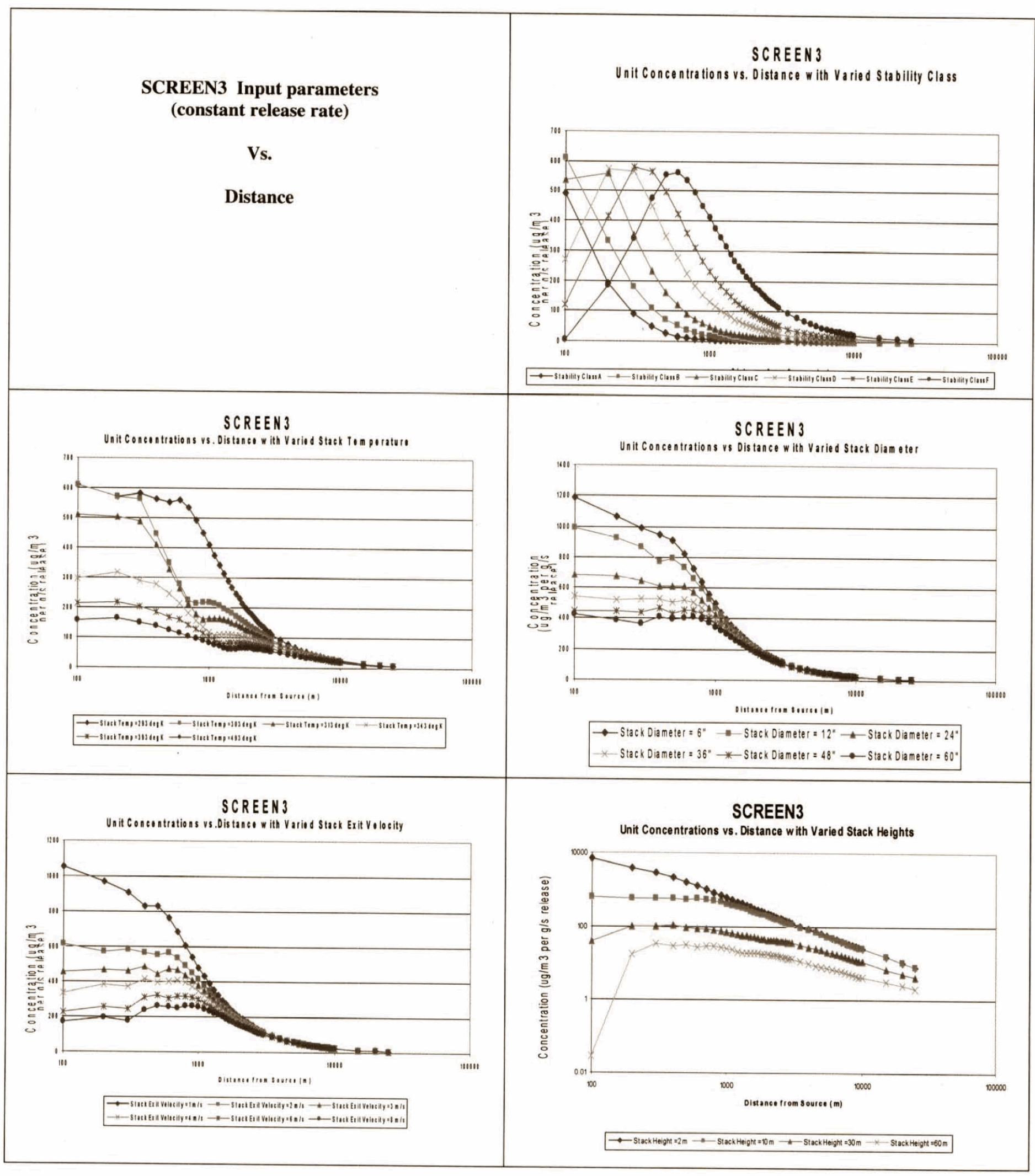




\section{IMPACTS OF SIIRINKING HIANFORD BOUNDARIES}

The current approval orders for the three referenced permit applications rely on the assumption that the nearest public receptor is about $\mathbf{2 0}$ miles away from the facilities. If the Hanford boundary shrinks in the next decade or so, the nearest public receptor could be much closer, on the order of a few kilometers. Questions about exceeding ASIL concentrations need to be answered well in advance of any decisions to move the restricted boundaries..

This project will investigate the use of the simple SCREEN3 model in conjunction with joint freçuency tables for weather data. The Pacific Northwest National Laboratory has published joint frequency distributions of atmospheric stability, wind speed, and transport direction, based on 20 years of weather data from the Hanford Meteorological

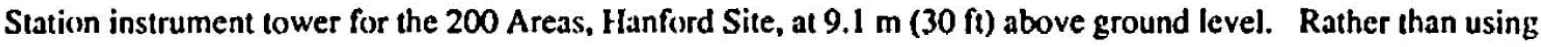
hourly meteorological data and a lengthy process for each run using ISC3, it may be feasible to build a data base using the percentages of time for each cardinal direction and wind speed category, using the results for 36 separate SCREEN3 runs for the associated wind speed/stability categories. Summing the concentration results for the respective atmospheric stability classes and average wind speed categories for each of the 16 cardinal directions in the joint frequency distribution tables should provide comparable results to the previous ISC3 model runs. Preliminary discussions with EPA on this approach have been favorable. The ability to look up a screening estimated concentration result from a table of unit concentration factors for specific distances and directions from a facility in the Hanford Site 200 Areas would be a useful tool. If conservative screening results are close to current permit limitations, more detailed modeling can be performed using specific stack parameters, to evaluate whether ambient concentrations in excess of standards are a valid concern. 


\section{REFERENCES}

40 CFR 51, Appendix W to Part 51 - Guideline on Air Quality Mlodels, as amended, Environmental Protection Agency, Washington, D. C.

DOE/RL-2000-21, Revision 0, Nonradioactive Air Emissions Notice of Construction Application for the Centra! Waste Complex for Storage of Vented Waste Containers, 2000, U.S. Department of Energy, Richland Operations Office, Richland, Washington.

DOE/RL-2001-17, Revision 0 Nonradioactive Air Emissions Notice of Construction Application for Toxic Air Pollutant Emissions at the T Plant Complex, 2001, U.S. Department of Energy, Richland Field Office, Richland, Washington.

DOE/RL-2001-45, Revision 1, Criteria/Toxics Air Emissions Notice of Construction Application for the Waste Receiving and Processing Facility, 2002, U.S. Department of Energy, Richland Field OMice, Richland, Washington.

PNNL-6415, Revision 15, Hanford Site National Environmental Policy Act (NEPA) Characterization, 2003, Pacific Northwest National Laboratory, Richland, Washington. 